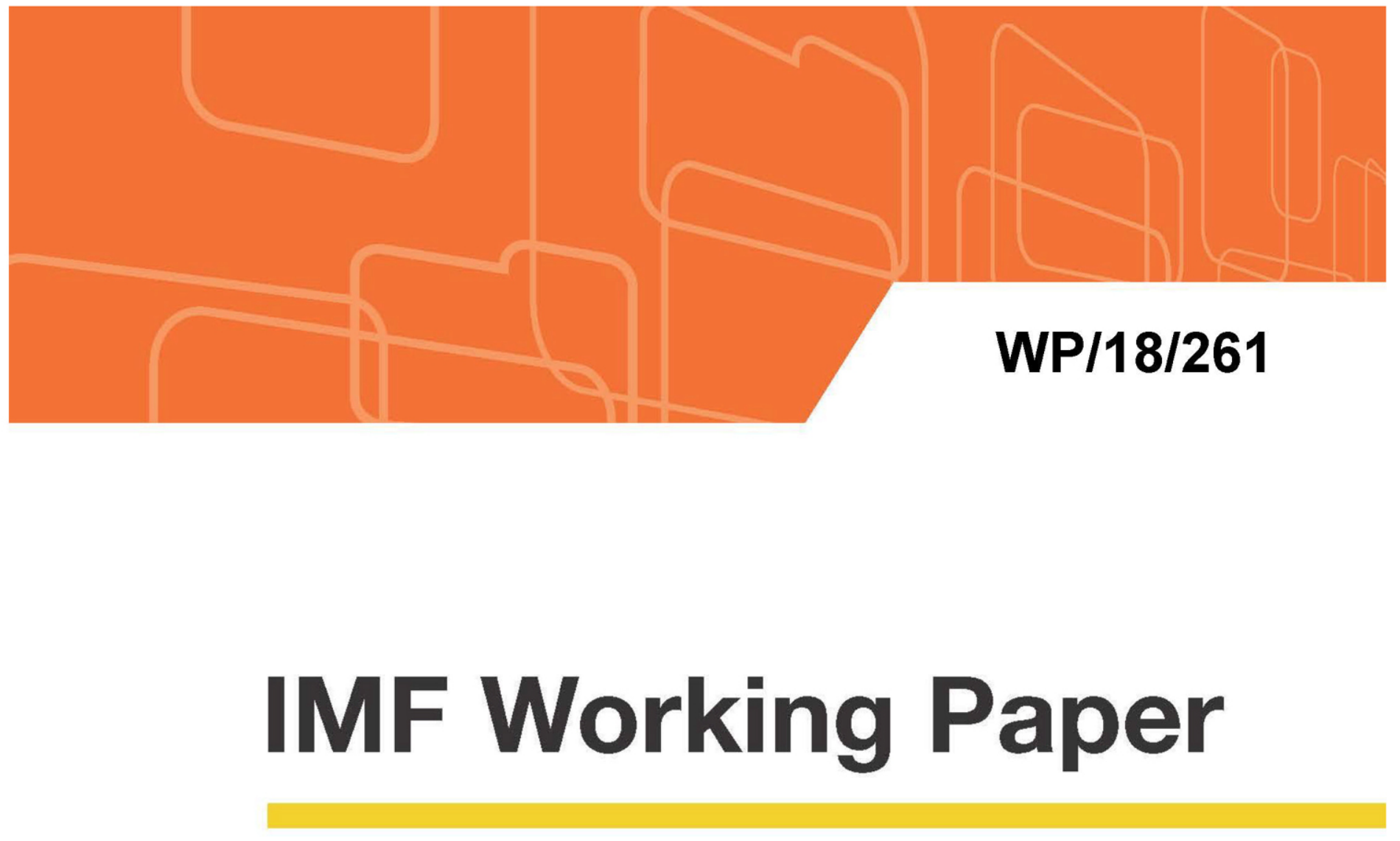

\title{
The Long-Run Trend of Residential Investment in China
}

by Ding Ding and Weicheng Lian

IMF Working Papers describe research in progress by the author(s) and are published to elicit comments and to encourage debate. The views expressed in IMF Working Papers are those of the author(s) and do not necessarily represent the views of the IMF, its Executive Board, or IMF management.

$$
\text { I N T E R N A T I O N A L M O N E T A R Y F U N D }
$$




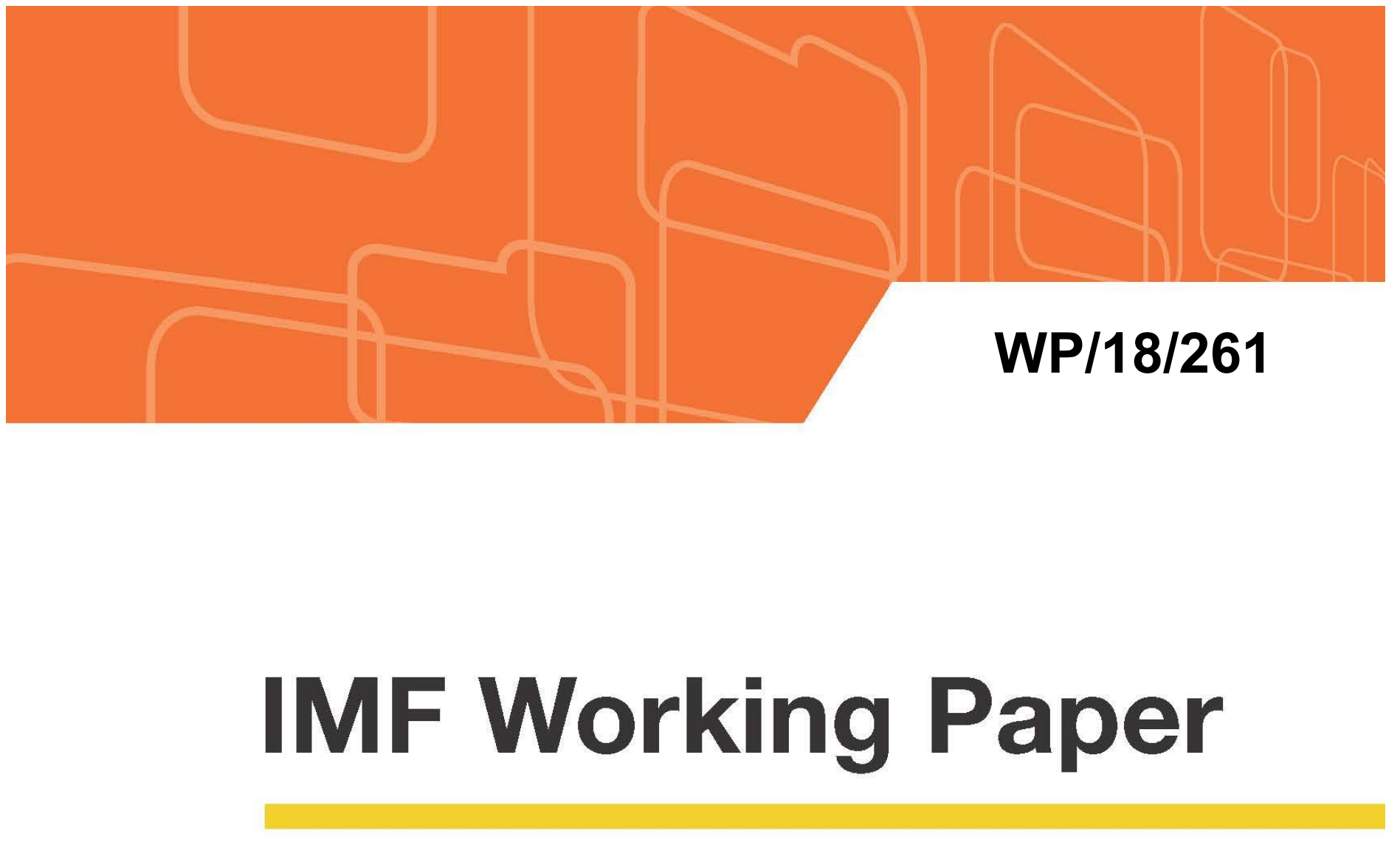

\section{The Long-Run Trend of Residential Investment in China}

by Ding Ding and Weicheng Lian

IMF Working Papers describe research in progress by the author(s) and are published to elicit comments and to encourage debate. The views expressed in IMF Working Papers are those of the author(s) and do not necessarily represent the views of the IMF, its Executive Board, or IMF management.

$$
\text { I N T E R N A T I O N A L M O N E T A R Y F U N D }
$$




\title{
IMF Working Paper
}

Asia and Pacific Department

\section{The Long-Run Trend of Residential Investment in China \\ Prepared by Ding Ding and Weicheng Lian ${ }^{1}$}

Authorized for distribution by James Daniel

December 2018

\section{IMF Working Papers describe research in progress by the author(s) and are published to elicit comments and to encourage debate. The views expressed in IMF Working Papers are those of the author(s) and do not necessarily represent the views of the IMF, its Executive Board, or IMF management.}

\begin{abstract}
In this paper we analyze the fundamental drivers of China's residential investment as a share of its GDP. Our analysis indicates that the economic structural changes that led to rebalancing toward consumption were the key driver of the rising residential investment to GDP ratio in China. We project that residential investment would moderate from the current level of 9 percent of GDP to around 6 percent by 2024, and its contribution to real GDP growth would decline gradually from currently about half percent of GDP to slightly negative over this period, barring policy intervention. The decline in the growth contribution of residential investment reflects the projected somewhat slower pace of rebalancing going forward and the envisaged increases in labor costs due to demographic changes.

JEL Classification Numbers: C11, C32, E43, E52, E58, F32, R31

Keywords: China housing market, residential investment, rebalancing

Author's E-Mail Address: dding@imf.org, wlian@,imf.org

\footnotetext{
${ }^{1}$ Ding Ding and Weicheng Lian are economists at the International Monetary Fund. They would like to thank James Daniel, Sonali Jain-Chandra, Markus Rodlauer, Yu Shi and participants at the IMF Asia and Pacific Department seminar for helpful comments. Jiayi Zhang provided excellent research assistance. The usual disclaimer applies.
} 


\section{Introduction}

Residential housing investment has been a key growth engine for China since urban housing commercialization took off in the late 1990s. The country's total housing investment grew from about 4 percent of GDP in 1997 to the peak of 15 percent of GDP in 2014, with residential investment accounting for more than two thirds of it. By cross-country standards, China's current residential investment as a share of GDP is well above that of countries with similar real household income levels (adjusted for the purchasing power parity and inflation).

Various distortions render China's property

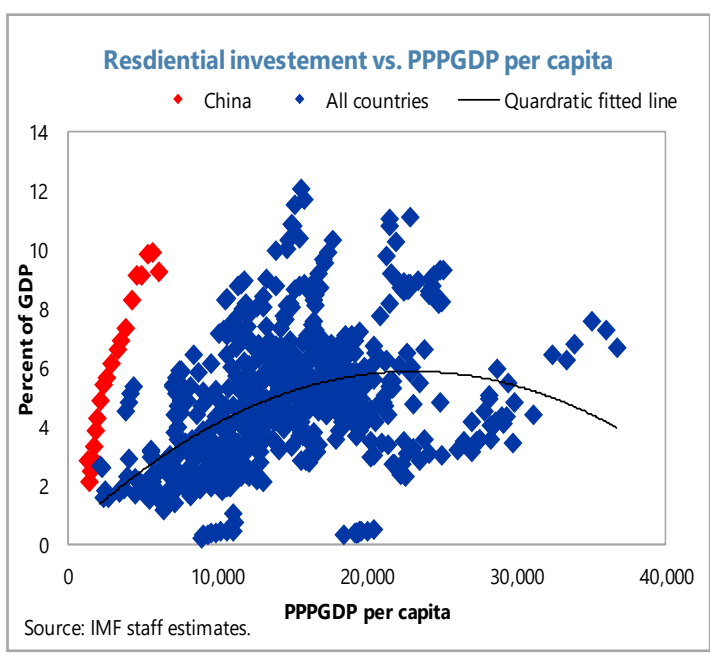
market susceptible to both price misalignment and overbuilding (Ding et al 2017). On the supply side, the market is distorted by local governments' control over land supply and their reliance on land sales to finance spending. On the demand side, the market is prone to overvaluation - housing is attractive as an investment instrument given a history of robust capital gains, high savings, low real deposit interest rates, a lack of alternative financial assets, capital account restrictions and more recently, a rapid increase in mortgage loans as banks seek to maintain the pace of asset expansion amid slower corporate credit growth. Given the importance of real estate in the overall economy, the government also had the tendency boost housing activity during economic downturns, creating the expectation that housing is "too important to fail."

Realizing the risks of the frequent housing boom-bust cycles, the Chinese government recently announced plans to develop a "long-term mechanism" for the residential housing market. Unlike the previous housing market policies which relied on administrative measures such as home purchase restrictions and macroprudential tools to manage house price cycles, the "long-term mechanism" aims to ensure sustained and stable development of the residential market by striking a balance between supply and demand while curbing speculation. Key elements of the mechanism include: (1) increasing land supply in cities where housing prices face stiff upward pressure by converting rural collective land and urban commercial land to residential land; (2) enhancing affordability by developing the rental market and expanding social housing including through the shanty town renovation program; (3) reducing property market pressure in mega cities by developing urban clusters and satellite cities with improved public services and transportation; (4) maintaining prudential standards on mortgage lending to help contain speculation; and (5) introducing a recurrent property value tax.

If this "long-term mechanism" takes hold, China's residential housing market should be determined mostly by fundamental housing demand and supply factors. Many of the underlying drivers behind the strong growth in China's housing market over the last two 
decades, such as the strong growth of household income and the pace of urbanization, are bound to face a secular slowdown due to the transition of the Chinese economy to a "new normal" and demographic changes. To the extent that housing investment should reflect these trends, the growth rate of residential investment would decline but the long-run equilibrium of residential investment as a share of GDP would also depend on the envisaged structural changes of the economy toward consumption-and-services-driven growth.

In this paper we examine the underlying drivers of housing investment as a share of GDP using cross-country evidences. The empirical analysis allows us to project the long-run trend of housing investment in China and its contribution to growth. We develop a two-step approach to control for endogeneity of house prices and the structural changes of the economy. This approach differs from the previous literature which studied China's housing investment in a "partial equilibrium" setting and were unable to incorporate the simultaneous impact of housing investment on nominal GDP. ${ }^{2}$ In contrast, we focus on the residential investment-to-GDP ratio rather than residential investment itself. The dependent variablethat is thus more likely to be stationary and less vulnerable to spurious regression issues.

The rest of the paper is organized as follows. Section II presents the methodology that consists of a decompostion of the redidential investment to GDP ratio into terms corresponding to structural factors of the economy, and cross-country empirical analysis in the following step to shed light on the relative contribution of such factors to long-run residential investment as a share of GDP. We present the results of the empirical analysis and project China's long-run trend of residential investment in Section III. We then discuss the policy implications in Section IV.

\section{Methodology}

The main contribution of this paper is that we develop a two-step approach to control for the reverse causality from residential investment to GDP growth. In the first step, residential investment to GDP ratios are decomposed into three terms together with a residual, based on an accounting identity as in Davis and Heathcote (2007). In the second step, we conduct a cross-country regression analysis on the residual term. We can then predict the long-run equilibrium of China's residential investment based on the forecasts of these terms. The theoretic foundation of the two-step approach is included in Appendix III.

The decomposition of residential investment as a share of GDP (RIY) is motivated by the following accounting identity:

\footnotetext{
${ }^{2}$ For example, Chivakul et al (2015) estimated the long-run relationships between floor space per capita in China and a set of fundamental determinants of demand including household income, house prices, urbanization rate and population density. Based on the estimated relationships, the authors projected that the average annual growth rate of floor space sold is about 4.3 percent, which would imply a decline in residential investment as a share of GDP from 9 percent to around 7 percent over the medium term.
} 


$$
\begin{aligned}
R I Y_{t} \triangleq \frac{I_{t}^{S}}{Y_{t}} & =\frac{P_{t}^{S}\left(S_{t}-\left(1-\delta^{S}\right) S_{t-1}\right)}{Y_{t}}=\frac{P_{t}^{S}\left(S_{t}-\left(1-\delta^{S}\right) S_{t-1}\right)}{P_{t}^{C} C_{t}} \frac{P_{t}^{C} C_{t}}{Y_{t}} \\
& =\frac{d_{t}^{S} S_{t}}{P_{t}^{C} C_{t}} \times \frac{P_{t}^{C} C_{t}}{Y_{t}} \times \frac{P_{t}^{S}}{d_{t}^{S}} \times\left(1-\left(1-\delta^{S}\right) \frac{S_{t-1}}{S_{t}}\right) \\
= & \frac{P_{t}^{C} C_{t}}{Y_{t}} \times \frac{P_{t}^{S}}{d_{t}^{S}} \times\left(1-\left(1-\delta^{S}\right) \frac{P_{t-1}^{C} C_{t-1}}{P_{t}^{C} C_{t}} \frac{d_{t}^{S}}{d_{t-1}^{S}}\right) \mathrm{e}^{\varepsilon_{t}}
\end{aligned}
$$

in which $d_{t}^{S}=P_{t}^{S}-\left(1-\delta^{S}\right) \frac{P_{t+1}^{S}}{R_{t}}$ is the user cost of housing structures, $S_{t}$ the residential structures stock (a house consists of land and structures, but only the change of structures stock is considered residential investment in the statistics of national accounts), $Y_{t}$ the nominal GDP, $P_{t}^{C} C_{t}$ nominal consumption, $P_{t}^{S}$ the deflator of residential investment, $\delta^{S}$ the depreciation rate of residential structure and $\varepsilon_{t}$ the residual term. ${ }^{3}$

The key transformation in the above accounting identity is to convert residential investment to changes in the stock of residential structures: $R I_{t}=S_{t}-\left(1-\delta^{S}\right) S_{t-1}$, which is a standard equation in a perpetual inventory method, and proxy $S_{t}$ (which is difficult to measure for a wide range of countries) using nominal consumption expenditure $P_{t}^{C} C_{t}$ and the user cost of structures $d_{t}^{S}$.

As houses are considered durable goods, the recurrent costs of owning a house (including mortgages, maintenance, and real estate taxes, offset by appreciation of the value of the house) often determines the amount of housing consumption (and residential investment) in the economy. The economic interpretations of the three terms in the above equation are:

- The consumption to GDP ratio. Housing services are not easily substitutable by other consumption goods. Higher income leads households to increase their expenditures not only on consumption goods, but also on home renovation and moving up the property ladder. In this regard, the rapid increase in China's residential investment to GDP ratio in the last decade can be associated with the steady rebalancing of the economy which saw rising consumption as a share of GDP. This rebalancing is expected to continue going forward, albeit at a more modest pace - the consumption to GDP ratio, having increased from 48 percent in 2010 to 54 percent in 2017 , is projected to rise further to 58 percent by 2024 according to the IMF staff's lastest projection (IMF 2018).

- The deflator to cost ratio of residential structures. If there is an increase in the expected returns of owning a house, possibly driven by lower interest rates or stronger risk appetite of investors, the price deflator would increase relative to the cost of residential structures, leading to higher ratio of residential investment to GDP.

\footnotetext{
${ }^{3}$ The cost in purchasing land is not part of residential investment. Importantly, the accounting decomposition uses the deflator of structures rather than the price of housing here. The user-cost-of-structures is much easier to compute than the user-cost-of-housing, because the price of housing is subject to sentiments and structure prices are mainly determined by productivity differential between the construction sector and the rest of the economy, implying more steady movements of structure prices than house prices.
} 
- The growth of consumption relative to the growth of the cost of residential structures. This term plays an important role in pining down residential investment especially when the growth of consumption and the growth of the cost of structures decouples. As shown in the above equation, if the cost of structures grows fasters than consumption growth, it creates downward pressure on residential investment. As the construction sector is labor intensive, the user-cost-of-structures is sensitive to labor costs (Bentolila and Saint-Paul 2003).

The residual, or the difference between the residential investment to GDP ratio and the sum of the above three terms, can be driven by the following factors: ${ }^{4}$

- Urbanization, measured by the change in urban share in population, could lead to more construction of new housing to cater to the demands of migrants. On the other hand, a larger share of population living in urban areas (or a higher population density) could reduce residential investment to GDP ratio due to land supply restrictions (see Glaeser et al 2006 and Davis and Palumbo 2008).

- Expectation about future housing price and income growth. In particular, speculative demand for housing can directly affect the residential investment to GDP ratio (Choi, Harrison and Scheinkman 2014).

To put China's residential investment dynamics into perspective, we compare it to that in the United States. A residential investment boom took place in China during the period between 2004 and 2016, the same time when the U.S. experienced a decline in residential investment as a share of GDP. Decomposition of the residential investment to GDP ratio indicates that the different residential investment dynamics between the two countries did not come from their respective consumption as a share of GDP which is broadly stable in both countries. The divergence could not be explained by the increase in the price to use cost ratio of structures either. Rather, it is the third channel identified in our decomposition equation - the growth of consumption relative to that of the cost of residential structures - that can explain the increase in China's residential investment to GDP ratio relative to that in the U.S. While both consumption and the cost of residential structures rose faster in China than in the U.S., it was China's faster consumption growth during 2004-16 that seems to be driving the country's residential investment boom.

\footnotetext{
${ }^{4}$ In this analysis we do not attempt to estimate the impact of any particular driver, which presumably can affect all the channels. Instead, we focus on how these terms and the drivers of the residual are predicted to change over time.
} 
Decomposition of the Residential Investment to GDP Ratio of China and the U.S.
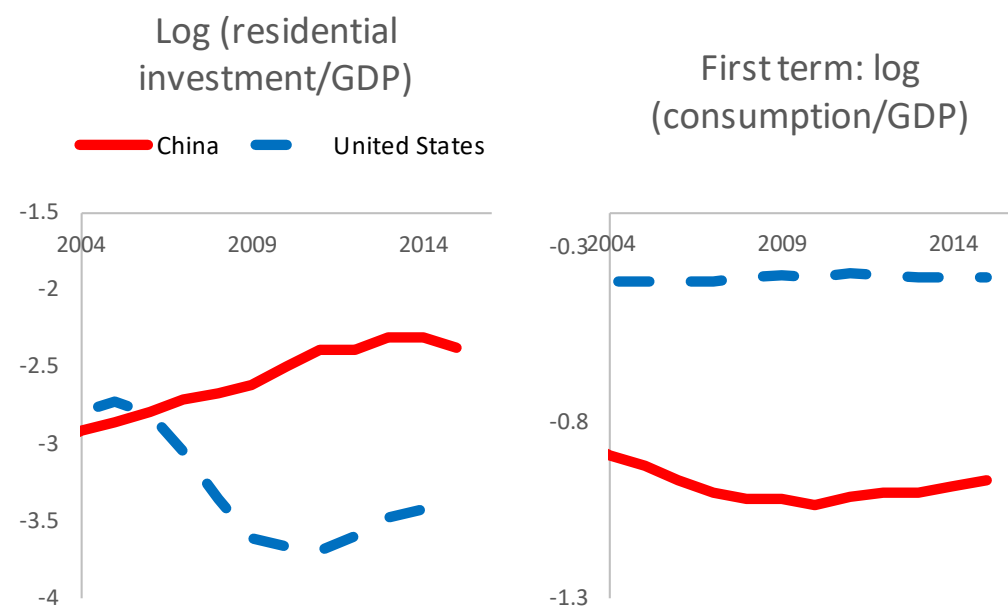

Second term: log (residential structure deflator/user costs of residential structure)

Third term: log (growth in residential structure quantity)
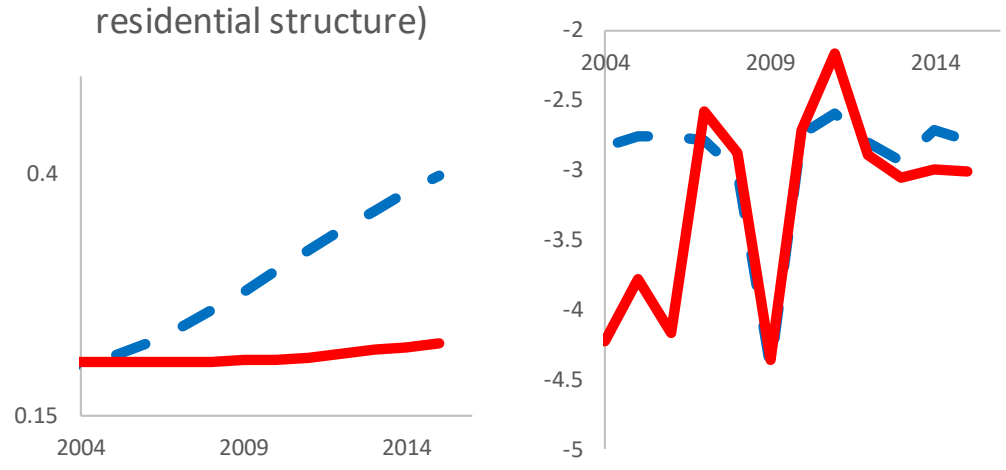

Behind the third term: consumption - China vs. United States

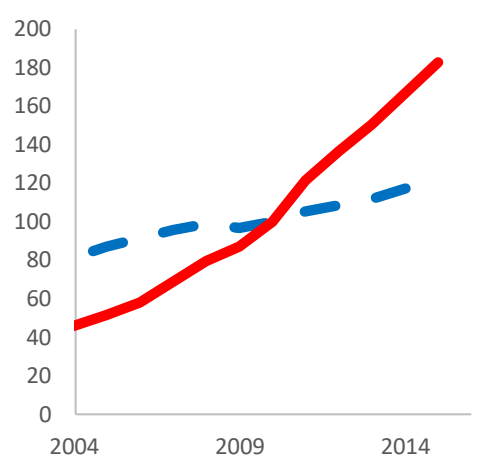

Behind the third term: user cost of structures China vs. United States

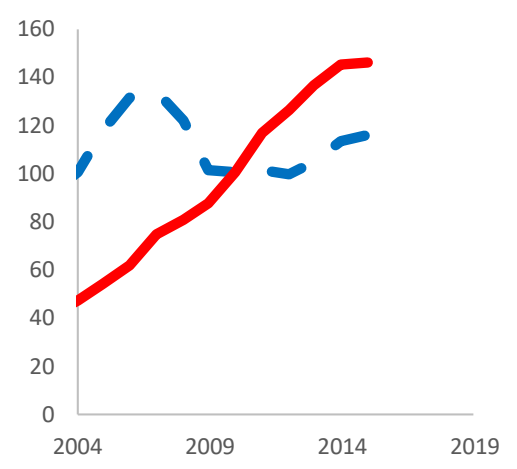


What may have caused the rapid increase in the cost of residential structures in China? According to Bentolila, and Saint-Paul (2003), the construction sector has the highest labor share among all industries. If wage cost grows faster than that of the labor productivity, it can drive up the unit labor cost. Although the lack of sectoral data prevents us from examining productivity growth in China's construction sector, Davis and Heathcote (2005) find that the total factor productivity (TFP) growth in the construction sector has been close to zero in the postwar period in the United States. Given that annual nominal wage growth in China has remained above 10 percent since the early 2000s (Das and N'Diaye 2013), it seems approporatie to attribute the the rising cost of residentital structures in China to the rapid growth in the wage cost.

The residual term from the decomposition equation does not explain why China diverged from the U.S. in residential investment. A further analysis of the residual term suggests that urbanization and speculation in the housing market, the two factors that the literature often highlights as the drivers of housing investment in China, do not seem to have played a significant role in the increase in residential investment relative to GDP. To confirm this, we conduct a panel regression of the residual term with a sample covering 34 countries and spanning the period between 1980 and 2016 (see Appendix I for data sources). The results are presented in Appendix II and discussed in the next section.
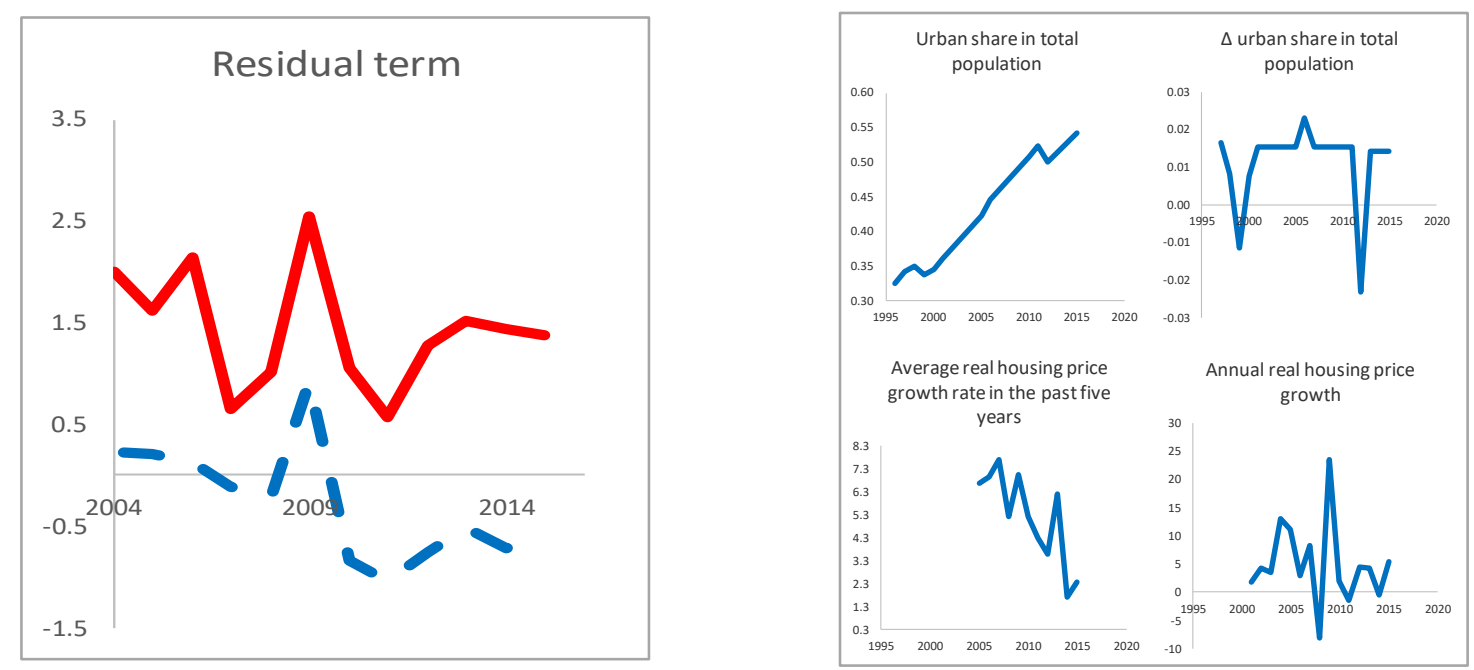

\section{Projection of China's Long-Run Residential Investment}

Contrary to the conventional wisdom, our empirical analysis indicates that urbanization or speculative demand for housing played limited role in driving China's residential investment boom. Cross-country regression of the residual term suggests that a higher share of urban population can put downward pressure on the residential investment to GDP ratio, perhaps due to the reduced supply of land for urban housing development. This negative effect, combined with China's steady pace of urbanization over the past two decades, suggest that 
the residential investment boom in 2004-16 was not caused by urbanization. ${ }^{5}$ Similarly, speculation of house prices is unlikely to be the cause of the residential investment boom, given the positive coefficient of the housing price growth shown in the regression results and the fact that growth of China's house prices has been moderating in the past decade.

It is worth noting that we did not find robust cross-country evidence of the impact of credit for the residual term. However, our analysis does not "exclude" the role of the credit boom in driving residential investment, as credit can be behind the consumption growth. Similarly, we do not exclude the impact of rising housing prices on consumption through the wealth effect channel. Our results simply illustrate an insignificant role of housing speculation in driving long-run housing investment dynamics.

These results suggest that the increase in China's residential investment to GDP ratio over the last decade is indeed related to the structural changes in the economy that led to rising consumption. Based on the envisaged strucutal change of the Chinese economy over the long run, we project China's residential investment to GDP ratio to gradually moderate to the pre-boom level over the medium term. Residential investment's contribution to GDP growth would decline gradually from currently about half percent of GDP to - 0.1 percent over

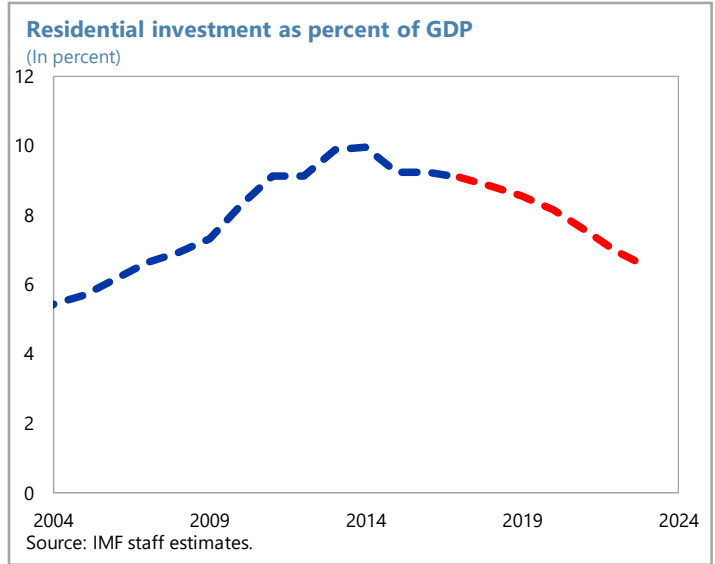
this period.

A key driver of the envisaged decline is the projected moderation of consumption growth relative to the growth of the costs of residential structures (represented by the third term in the decomposition equation). This reflects the diminishing "base" effects as consumption growth is projected to moderate from 14 percent during the residential investment boom in 2010-15 to less than 9 percent by 2024, as well as the rising labor costs due to population aging or reduced working-age population. In particular, the real user cost of structures is assumed to grow at around 5 percent between 2019 and 2029, which is slightly lower than the average of 5.4 percent between 2009 and 2018. ${ }^{6}$ This impact dominates the direct positive impact of rebalancing (the projected further, albeit slower, increase in consumption as a share of GDP) on residential investment, represented by the first term in the decomposition equation.

\footnotetext{
${ }^{5}$ In Appendix III, Table 2 shows that the coefficient of the level of urbanization is negative if we do not add a quadratic term and becomes insignificant if it is added. This pattern may reflect the fact that the negative effect of higher level of urbanization on residential investment is weaker in emerging market and developing economies (EMDEs) and the sample being dominated by advanced economies (AEs). We find that if the analysis is restricted to EMDEs, the urbanization-level coefficient becomes insignificant, which is also shown in Table 2.

${ }^{6}$ This assumption implies that the labor income share in China will be broadly stable between 2019 and 2029.
} 


\section{Policy Implications}

In this paper we demonstrate that the residential investment to GDP ratio can be decomposed into several terms representing different underlying drivers. These drivers can capture the different impact of structural changes in the economy on residential investment, including rebalancing, urbanization, housing market speculation and a possible divergence between the price and the cost of residential structures. This decomposition method allows us to study the drivers of residential investment as a share of GDP ratio controlling for the endogeneity that is often neglected in the "partial equilibrium" settings. Our results indicate that the income growth and economic rebalancing are important forces for the relative GDP contribution of residential investment.

Based on the long-run trend of the Chinese economy and the demographics, we project that China's residential investment to GDP ratio would moderate over time. The ratio is projected to decline from currently around 9 percent of GDP to 6 percent of GDP by 2024. To the extent that this decline reflects the rebalancing of the economy and its transition to slower but more sustainable growth, the government should avoid preventing such a decline. In particular, the government should move away from the practice of setting high annual growth targets that has at times fostered an undesirable focus on boosting real estate activity through credit to achieve them.

That said, given the importance of housing in the Chinese economy, a sharp decline in residential investment should be avoided. In this regard, pro-rebalancing policies such as a more progressive tax system and higher spending on social transfers could boost consumption and ameliorate income inequality, which in turn would support demand for housing. In the context of developing the "long-term mechanism" for housing, the government should also further promote social and rental housing and liberalize land supply, which would create additional demand for housing, directly via improved affordability and indirectly via the positive impact on rebalancing, and thus support a more gradual adjustment in the residential real estate market. 


\section{References}

Bentolila, Samuel, and Gilles Saint-Paul, 2003, "Explaining Movements in the Labor Share." Contributions in Macroeconomics 3, no. 1 (2003).

Chivakul, M., W.R. Lam, X. Liu, W. Maliszewski, and A. Schipke, 2015, "Understanding Residential Real Estate in China”, IMF Working Paper No.15/84.

Choi, Hyun-Soo, Harrison Hong, and Jose Scheinkman, 2005, "Speculating on home improvements." Journal of Financial Economics 111, no. 3 (2014): 609-624.

Davis, Morris A., and Jonathan Heathcote. "Housing and the business cycle." International Economic Review 46, no. 3: 751-784.

Davis, Morris A., and Michael G. Palumbo, 2008, "The price of residential land in large US cities." Journal of Urban Economics 63, no. 1: 352-384.

Davis, Morris A., and Jonathan Heathcote, 2007, "The price and quantity of residential land in the United States." Journal of Monetary Economics 54, no. 8: 2595-2620.

Das, M. and P. N’Diaye, 2013, “Chronicle of a Decline Foretold: Has China Reached the Lewis Turning Point?” IMF Working Paper 13/26.

Ding, Ding, Xiaoyu Huang, Tao Jin and W. Raphael Lam, 2017, “Assessing China’s Residential Real Estate Market, “” IMF Working Paper N0. 17/248.

Epple, Dennis, Brett Gordon, and Holger Sieg, 2010, "A new approach to estimating the production function for housing." American Economic Review 100, no. 3: 905-24.

Garriga, Carlos, Rodolfo E. Manuelli, and Adrian Peralta-Alva, 2012, "A Model of Price Swings in the Housing Market." Federal Reserve Bank of St. Louis Working Paper Series 2012-022.

Glaeser, Edward L., Joseph Gyourko, and Raven Saks, 2005, "Why have housing prices gone up?” National Bureau of Economic Research. No. w11129.

Lian, Weicheng, 2018, "Fundamental and Speculative Demands for Housing”, working paper.

McDonald, John F, 1981, "Capital-land substitution in urban housing: A survey of empirical estimates." Journal of urban Economics 9, no. 2: 190-211.

Thorsnes, Paul, 1997, "Consistent estimates of the elasticity of substitution between land and non-land inputs in the production of housing." Journal of Urban Economics 42, no. 1: 98108. 


\section{Appendix I. Data Sounces}

A set of AEs and EMDEs are included in the sample and listed in Table 1. The inclusion of a country in the sample is mainly constrained by the availability of the deflator of residential investment.

\section{Table 1. Countries in the Sample}

\section{Advanced economies}

Australia, Austria, Belgium, Canada, Czech Republic, Denmark, Finland, France, Germany, Greece, Japan,Korea, Netherlands, New Zealand, Norway, Portugal, Singapore, Slovak Republic, Slovenia, Spain, Sweden, Switzerland, United Kingdom, and United States

\section{Emerging market and developing economies}

Chile, China, Hungary, India, Indonesia, Malaysia, Mexico, Poland, Russia, and South Africa

\section{Table 2 Variables and Data Sources}

Table 2 reports the sources of the data, including those used in the decomposition. Following Lian (2018), we choose the depreciation rate $\delta^{S}$ as 3.5 percent per year.

\begin{tabular}{|c|c|}
\hline Variables & Sources \\
\hline $\begin{array}{l}\text { Deflators of residential investment }\left(\mathrm{P}_{\mathrm{t}}^{\mathrm{S}}\right) \text {, deflators of private consumption }\left(\mathrm{P}_{\mathrm{t}}^{\mathrm{C}}\right) \text {, } \\
\text { residential investment }\left(\mathrm{I}_{\mathrm{t}}^{\mathrm{S}}\right) \text {, private consumption }\left(\mathrm{C}_{\mathrm{t}}\right) \text {, GDP }\left(\mathrm{Y}_{\mathrm{t}}\right) \text {, Actual and } \\
\text { expected GDP growth rates }\end{array}$ & $\begin{array}{l}\text { World Economic Outlook database, OECD } \\
\text { statistics, } \\
\text { Eurostats, and Consensus Forecast database }\end{array}$ \\
\hline Value-added share of the construction sector & $\begin{array}{l}\text { Groningen Growth and Development Center } \\
10 \text {-sector database }\end{array}$ \\
\hline share of population living in urban areas & World Bank Development Indicators \\
\hline $\begin{array}{l}\text { Lending rates (a proxy for interest rates in the construction of structure } \\
\text { user costs) }\left(R_{t}\right)\end{array}$ & International Financial Statistics \\
\hline Housing prices & $\begin{array}{l}\text { Jorda-Schularick-Taylor Macrohistory database, } \\
\text { Global Housing Watch }\end{array}$ \\
\hline Home ownership status (used to compute homeownership rate) & IPUMS \\
\hline Credit gaps & Bank of International Settlements \\
\hline
\end{tabular}




\section{Appendix II. Regression Results: Factors Driving the Residual Term in the Decompostion Equation of Residential Investment to GDP Ratio}

The empirical strategy to separate the roles of different structural factors is to first compute the impacts from fundamental determinants of residential investment using the accounting identity specified in equation (1), and then analyze the underlying factors behind the residual term. The fundamental forces that impact residential investment to GDP ratio are further analyzed theoretically in appendix III.

The regression analyzing the residual term is as follows:

$$
\begin{aligned}
\varepsilon_{i, t}=\alpha_{i} & +\mu_{t}+\beta_{1} \frac{\operatorname{Pop}_{i, t}^{\text {Urban }}}{\operatorname{Pop}_{i, t}}+\beta_{2}\left(\frac{\operatorname{Pop}_{i, t}^{\text {Urban }}}{\operatorname{Pop}_{i, t}}\right)^{2}+\beta_{3} \Delta \frac{\operatorname{Pop}_{i, t}^{\text {Urban }}}{\operatorname{Pop}_{i, t}} \\
& +\rho g_{i, t-5 \rightarrow t}^{\text {Housing price }}+\varphi \omega_{i, t}+v_{i, t}
\end{aligned}
$$

where $i$ denotes country, $t$ denotes year, $\varepsilon_{i, t}$ is the residual term, $\alpha_{i}$ is the country fixed effect, $\mu_{t}$ is the time fixed effect, $\frac{\mathrm{Pop}_{i, t}^{\mathrm{Urban}}}{\mathrm{Pop}_{i, t}}$ is the share of population living in urban area, $g_{i, t-5 \rightarrow t}^{\text {House price }}$ is the average growth rate of housing price in the past five years, and $\omega_{i, t}$ is the homeownership rate. The share of population living in the urban area and the average housing price growth capture the impact of urbanization and speculation in housing markets on residential investment.

As AEs and EMDEs are at different stages of the urbanization process, the column (5) reports the estimates for EMDEs only. The forecast of residential investment to GDP ratio between 2019 and 2029 in China is based on these results. As the coefficient of the share of population living in urban area is not significant, we set the impact of the level of urbanization on residential investment to GDP ratio to be zero in the projection.

In results not reported here, we use credit gaps and expected output growth as additional control variables and do not find them to be significant variables explaining the residual term. 
Table 3 Estimation of the Factors Driving the Residual Term

\begin{tabular}{|c|c|c|c|c|c|c|}
\hline & All & All & All & ALL & EMDES & ALL \\
\hline VARIABLES & $(1)$ & $(2)$ & (3) & (4) & (5) & (6) \\
\hline Urban share in population & $\begin{array}{c}0.493 \\
(0.382)\end{array}$ & $\begin{array}{c}-9.419 * * * \\
(1.569)\end{array}$ & $\begin{array}{c}-4.901^{* *} \\
(1.989)\end{array}$ & $\begin{array}{c}15.41 \\
(11.86)\end{array}$ & $\begin{array}{l}-1.263 \\
(4.139)\end{array}$ & $\begin{array}{l}-4.844 \\
(5.398)\end{array}$ \\
\hline$(\text { Urban share in population })^{\wedge} 2$ & & & & $\begin{array}{l}-12.91^{*} \\
(7.433)\end{array}$ & & \\
\hline$\Delta$ urban share in population & $\begin{array}{l}-0.823 \\
(2.654)\end{array}$ & $\begin{array}{c}3.637 \\
(2.297)\end{array}$ & $\begin{array}{c}1.514 \\
(2.331)\end{array}$ & $\begin{array}{c}1.798 \\
(2.331)\end{array}$ & $\begin{array}{c}1.008 \\
(4.103)\end{array}$ & $\begin{array}{c}0.192 \\
(4.896)\end{array}$ \\
\hline Past five year growth of real housing prices & $\begin{array}{c}0.0270^{* * *} \\
(0.00927)\end{array}$ & $\begin{array}{l}0.0185^{* *} \\
(0.00883)\end{array}$ & $\begin{array}{l}0.0195 * * \\
(0.00989)\end{array}$ & $\begin{array}{c}0.0186^{*} \\
(0.00988)\end{array}$ & $\begin{array}{l}5.61 \mathrm{e}-05 \\
(0.0178)\end{array}$ & $\begin{array}{c}-0.00732 \\
(0.0216)\end{array}$ \\
\hline Homeownership rate & & & & & & $\begin{array}{c}0.00799 \\
(0.00854)\end{array}$ \\
\hline Country fixed effects & $\mathrm{N}$ & Y & Y & Y & Y & $\mathrm{Y}$ \\
\hline Year fixed effects & $\mathrm{N}$ & $\mathrm{N}$ & Y & Y & Y & Y \\
\hline Observations & 460 & 460 & 460 & 460 & 122 & 230 \\
\hline R-squared & 0.024 & 0.418 & 0.503 & 0.507 & 0.706 & 0.483 \\
\hline
\end{tabular}

Standard errors in parentheses

*** $p<0.01,{ }^{* *} p<0.05,{ }^{*} p<0.1$ 


\section{Appendix III. Theoretical foundation for the two-step approach}

This appendix provides a theoretical analysis about the fundamental factors that impact the ratio of residential investment over output. The household preference $U$ is defined over housing services $h\left(L_{t}, S_{t}\right)$, which are produced from land and structures, and other general goods $Z_{t}: U\left(h\left(L_{t}, S_{t}\right), Z_{t}\right)$.

\section{The benchmark case: Cobb-Douglass Preference Function}

Consider $U\left(h\left(L_{t}, S_{t}\right), Z_{t}\right)=\left(L_{t}\right)^{\theta^{L}}\left(S_{t}\right)^{\theta^{S}}\left(Z_{t}\right)^{\theta^{Z}}$. Households spend a fixed portion of consumption expenditure on the housing services produced from residential structures:

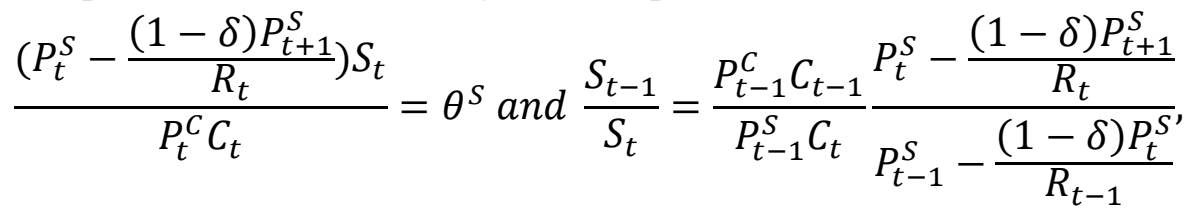

We decompose the ratio of residential investment over GDP as:

$$
R I Y_{t}=\log \left(\theta^{S}\right)+\log \left(\frac{P_{t}^{C} C_{t}}{Y_{t}}\right)+\log \left(1-\frac{P_{t-1}^{C} C_{t-1}}{P_{t}^{C} C_{t}} \frac{P_{t}^{S}-\frac{(1-\delta) P_{t+1}^{S}}{R_{t}}}{P_{t-1}^{S}-\frac{(1-\delta) P_{t}^{S}}{R_{t-1}}}\right)
$$

Define a residual term as follows: for country $i$ in year $\mathrm{t}$,

$$
\log \left(\varepsilon_{i, t}\right)=R I Y_{i, t}-\log \left(\frac{P_{i, t}^{C} C_{i, t}}{Y_{i, t}}\right)+\log \left(1-\frac{P_{i, t-1}^{C} C_{i, t-1}}{P_{i, t}^{C} C_{i, t}} \frac{P_{i, t}^{S}-\frac{(1-\delta) P_{i, t+1}^{S}}{R_{i, t}}}{P_{i, t-1}^{S}-\frac{(1-\delta) P_{i, t}^{S}}{R_{i, t-1}}}\right)
$$

\section{Zero Elasticity of Substitution between Land and Structures}

Suppose the substitutability between land and structures is lower than what is implied by the Cobb-Douglass production function (McDonald (1981), Lian (2018), Garriga, Manuelli, and

Peralta-Alva (2018)). The residual term defined above is no longer a constant. To reveal this, the simplest way is to consider a Leontief housing service production function:

$$
f\left(h\left(L_{t}, S_{t}\right), Z_{t}\right)=\left(\min \left(L_{t}, S_{t}\right)\right)^{1-\gamma}\left(Z_{t}\right)^{\gamma} .
$$

It is important to recognize that the limited substitutability between land and structures in producing housing services should not be interpreted as a technology constraint. Recent estimates by Thorsner (1997) and Epple et al. (2010) suggest that the production function of individual houses can be approximated by Cobb-Douglass production functions. Instead, the limited substitutability reflects zoning restrictions, leading to the difficulty of providing housing services through structures. 
The optimal choices of households satisfy:

$$
\left(P_{t}^{L}-\frac{P_{t+1}^{L}}{R_{t}}+P_{t}^{S}-\frac{(1-\delta) P_{t+1}^{S}}{R_{t}}\right) S_{t}=(1-\gamma) P_{t}^{C} C_{t}
$$

Therefore, the ratio of residential investment over output $\left(R I Y_{t}\right)$ can be decomposed into:

$$
\begin{gathered}
R I Y_{t}=\log \left(\frac{P_{t}^{S} S_{t}}{P_{t}^{C} C_{t}}\right)+\log \left(\frac{P_{t}^{C} C_{t}}{Y_{t}}\right)+\log \left(1-\frac{S_{t-1}}{S_{t}}\right) \\
=\log \left(\frac{\left(P_{t}^{S}-\frac{(1-\delta) P_{t+1}^{S}}{R_{t}}\right)(1-\gamma)}{P_{t}^{L}-\frac{P_{t+1}^{L}}{R_{t}}+\left(P_{t}^{S}-\frac{(1-\delta) P_{t+1}^{S}}{R_{t}}\right)}\right)+\log \left(\frac{P_{t}^{C} C_{t}}{Y_{t}}\right) \\
+\log \left(1-\frac{P_{t-1}^{C} C_{t-1}}{P_{t}^{C} C_{t}} \frac{P_{t}^{L}-\frac{P_{t+1}^{L}}{R_{t}}+\left(P_{t}^{S}-\frac{(1-\delta) P_{t+1}^{S}}{R_{t}}\right)}{P_{t-1}^{L}-\frac{P_{t}^{L}}{R_{t-1}}+\left(P_{t-1}^{S}-\frac{(1-\delta) P_{t}^{S}}{R_{t-1}}\right)}\right) .
\end{gathered}
$$

By definition, the residual term becomes

$$
\begin{array}{r}
\log \left(\varepsilon_{i, t}\right)=\log (1-\gamma)+\log \left(\frac{\left(P_{i, t}^{S}-\frac{\left.(1-\delta) P_{i, t+1}^{S}\right)}{R_{i, t}}\left(P_{i, t}^{L}-\frac{P_{i, t+1}^{L}}{R_{i, t}}+\left(P_{i, t}^{S}-\frac{(1-\delta) P_{i, t+1}^{S}}{R_{i, t}}\right)\right.\right.}{\left.P_{i, t+1}\right)}\right) \\
+\log \left(\begin{array}{c}
1-\frac{P_{i, t-1}^{C} C_{i, t-1}}{P_{i, t}^{C} C_{i, t}} \frac{P_{i, t}^{L}-\frac{P_{i, t+1}^{L}}{R_{i, t}}+\left(P_{i, t}^{S}-\frac{(1-\delta) P_{i, t-1}^{S}-\frac{P_{i, t}^{L}}{R_{i, t-1}}+\left(P_{i, t-1}^{S}-\frac{(1-\delta) P_{i, t}^{S}}{R_{i, t-1}}\right)}{P_{i, t-1} C_{i, t-1}}\right.}{P_{i, t}^{C} C_{i, t}} \frac{P_{i, t}^{S}-\frac{(1-\delta) P_{i, t+1}^{S}}{R_{i, t}}}{P_{i, t-1}^{S}-\frac{(1-\delta) P_{i, t}^{S}}{R_{i, t-1}}}
\end{array}\right)
\end{array}
$$

One interesting case is that if $P_{i, t}^{L}-\frac{P_{i, t+1}^{L}}{R_{i, t}}$ grows faster than $P_{i, t}^{S}-\frac{(1-\delta) P_{i, t+1}^{S}}{R_{i, t}}, \log \left(\varepsilon_{i, t}\right)$ should have a downward trend.

Once $\log \left(\varepsilon_{i, t}\right)$ is not a constant, housing policies can affect $\log \left(\varepsilon_{i, t}\right)$. For example, Glaeser, Gyourko, and Saks (2005) argue that the overly tight man-made housing supply constraints in the United States reduce the growth in housing quantity.

\section{Urbanization and residential investment to GDP ratio}

Urbanization impacts the ratio of residential investment over GDP through multiple channels. Demands of migrants for housing imply that faster speed of urbanization is associated with stronger residential investment. 
A less recognized link between urbanization and residential investment is through the relative role of residential structures and land in providing housing services. Intuitively, if land relative to residential structures becomes more important, we should expect to observe lower $\theta^{S}$ and hence smaller ratio of residential investment over GDP. This is a channel for urbanization to negatively impact residential investment.

Previous studies have suggested that perhaps due to more restricted housing regulations, land's role in housing supply has risen over time in the United States (Glaeser, Gyourko and Saks (2005) and Lian (2018)). Relatedly, the cross-metropolitan-statistical-area (MSA) data in the United States constructed by Davis and Palumbo (2008) suggest that the land's share in housing value tends to be higher in coastal areas. We regard such developments as prevalent in many economies, and more research is needed to explore this phenomenon. 